\title{
Evaluation of a Stable Gonadotropin-Releasing Hormone Analog in Mice for the Treatment of Endocrine Disorders and Prostate Cancer
}

\author{
Theodora Katsila, Evangelos Balafas, George Liapakis, Patrizia Limonta, \\ Marina Montagnani Marelli, Konstantinos Gkountelias, Theodore Tselios, \\ Nikolaos Kostomitsopoulos, John Matsoukas, and Constantin Tamvakopoulos
}

Division of Pharmacology-Pharmacotechnology, Biomedical Research Foundation, Academy of Athens, Athens, Greece (T.K., C.T.); Center for Experimental Surgery, Biomedical Research Foundation, Academy of Athens, Athens, Greece (E.B., N.K.); Department of Pharmacology, University of Crete, Heraklion, Crete, Greece (G.L., K.G.); Department of Endocrinology, Physiopathology, and Applied Biology, Università degli Studi di Milano, Milano, Italy (P.L., M.M.M.); and Department of Chemistry, University of Patras, Patras, Greece (T.T., J.M.)

Received August 25, 2010; accepted November 23, 2010

\begin{abstract}
Gonadotropin-releasing hormone $(\mathrm{GnRH})$ receptor agonists have wide clinical applications including the treatment of prostate cancer and endocrine disorders. However, such agonists are characterized by poor pharmacokinetic properties, often requiring repeated administration or special formulations. Therefore, the development of novel peptide analogs with enhanced in vivo stability could potentially provide therapeutic alternatives. The pharmacological evaluation of a bioactive peptide [Des-Gly ${ }^{10}, \mathrm{Tyr}^{5}(\mathrm{OMe}), \mathrm{D}^{\mathrm{L}} \mathrm{Leu}^{6}{ }^{6}$,Aze-NHEt ${ }^{9}$ GnRH, ana$\log 1$, is presented herein and compared with leuprolide. Peptide stability was evaluated using mouse kidney membrane preparations, followed by a liquid chromatography-tandem mass spectrometry-based approach that afforded identification and quantification of its major metabolites. The analog was significantly more stable in vitro in comparison with leuprolide. In vitro and in vivo stability results correlated well, encouraging
\end{abstract}

us to develop a clinically relevant pharmacokinetic mouse model, which facilitated efficacy measurements using testosterone as a biomarker. Analog 1, an agonist of the $\mathrm{GnRH}$ receptor with a binding affinity in the nanomolar range, caused testosterone release in mice that was acutely dose-dependent, an effect blocked by the $\mathrm{GnRH}$ receptor antagonist cetrorelix. Repeated dosing studies in mice demonstrated that analog 1 was well tolerated and had potency similar to that of leuprolide, based on plasma and testis testosterone reduction and histopathological findings. Analog 1 also shared with leuprolide similar significant antiproliferative activity on androgen-dependent prostate cancer (LNCaP) cells. On the basis of pharmacokinetic advantages, we expect that analog 1 or analogs based on this new design will be therapeutically advantageous for the treatment of cancer and endocrine disorders.

\section{Introduction}

Androgen deprivation therapy with gonadotropin-releasing hormone $(\mathrm{GnRH})$ analogs is considered to be the first-line treatment for patients with prostate cancer. In early-stage prostate cancer, disease development and progression are mediated by androgens and growth and survival factors that promote cell proliferation and inhibit apoptosis. A significant proportion of patients develop locally advanced or metastatic

This work was supported in part by the A. G. Leventis Foundation.

Article, publication date, and citation information can be found at http://jpet.aspetjournals.org.

doi:10.1124/jpet.110.174375 disease not amenable to surgery or radiotherapy (Labrie et al., 2005). Recent advances suggest that GnRH analogs not only inhibit testicular androgen secretion via the pituitarygonadal axis but are also capable of direct inhibition of tumor growth, exerting specific (receptor-mediated) antiproliferative, antimitogenic, and antimetastatic activities on cancer cells (Montagnani Marelli et al., 2006, 2007). Because several types of cancer cells overexpress the GnRH receptor, novel structures based on $\mathrm{GnRH}$ analogs that act as carriers to cancer cells, coupled with cytotoxic molecules (e.g., doxorubicin), have been prepared and evaluated in preclinical cancer models with promising results (Mezo and Manea, 2010).

Chronic administration of $\mathrm{GnRH}$ analogs results in the

ABBREVIATIONS: GnRH, gonadotropin-releasing hormone; LC, liquid chromatography; MS/MS, tandem mass spectrometry; LNCaP, lymph node carcinoma of the prostate; IS, internal standard; MS, mass spectrometry; HSA, human serum albumin; MRM, multiple reaction monitoring; EPI, enhanced product ion; QC, quality control; AUC, area under the curve. 
desensitization of the GnRH receptor and, hence, medical castration (Maudsley et al., 2004; Pawson et al., 2008). Moreover, according to their "dual pharmacology," GnRH analogs are also characterized by direct anticancer potential via their interference with growth and survival factors, such as insulin-like growth factor-I, epidermal growth factor, and keratinocyte growth factor (Culig et al., 1994; Montagnani Marelli et al., 2007). GnRH receptor agonists currently in clinical use (e.g., leuprolide) are superior to the native hormone $(\mathrm{GnRH})$ in terms of potency because of their high receptor affinity and improved proteolytic stability (Berger et al., 1991). However, GnRH analogs are still susceptible to the action of proteolytic enzymes (Haviv et al., 1992) and have limited absorption (Zheng et al., 1999) and low bioavailability (Adjei et al., 1993). As a consequence, these peptides are administered intramuscularly or subcutaneously and as depot formulations (Sennello et al., 1986; Perez-Marreno et al., 2002).

During the first days of their administration, GnRH receptor agonists are accompanied by the "flare phenomenon," in which the pituitary-gonadal axis is stimulated, thus resulting in the extensive release of gonadotrophs (10- and 5-fold increases in luteinizing hormone and follicle-stimulating hormone concentrations, respectively) and testosterone (Johns et al., 1990; Labrie et al., 2005). The flare phenomenon is an undesirable side effect that promotes metastasis. In the clinic, it can be managed by combined androgen blockade, which includes the coadministration of an antiandrogen (e.g., flutamide) and a GnRH receptor agonist (Wirth et al., 2007). As an alternative to $\mathrm{GnRH}$ receptor agonists, peptide antagonists have been synthesized and developed over the years. The administration of $\mathrm{GnRH}$ receptor antagonists does not cause the flare phenomenon, a considerable advantage in comparison with $\mathrm{GnRH}$ receptor agonists, but these agents have been associated with other side effects such as acute inflammation and require higher doses compared with agonists (Labrie et al., 2005; Kirby et al., 2009).

Considering the importance of hormonal therapy for the treatment of prostate cancer and the current needs for improved therapeutic approaches, we decided to focus on efforts to discover pharmacokinetically superior and possibly equipotent novel GnRH peptide analogs. Although superagonists have well established clinical benefits, their in vivo stability remains a limiting factor that most likely prevents them from exerting any direct effects on tumors (extrapituitary) or causing rapid desensitization of the GnRH receptor. After the development and establishment of in vitro and in vivo assays, coupled with liquid chromatography (LC)-tandem mass spectrometry (MS/MS) methodologies (Sofianos et al., 2008), analog 1 , a potent stable peptide, was chosen from a screen among other GnRH receptor peptide agonists/antagonists. In this article, we report our findings regarding analog 1 , [Des-

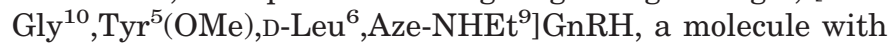
the conformational features required for agonistic activity (Matsoukas et al., 1997; Laimou et al., 2010) and enhanced in vitro and in vivo stability compared with leuprolide.

Although analog 1 has reduced binding affinity on the GnRH receptor compared with leuprolide, repeated dosing studies in mice demonstrated that analog 1 was well tolerated and had potency similar to that of leuprolide. Analog 1 was also endowed with significant antiproliferative activity on prostate cancer cells (LNCaP), similar to that exerted by leuprolide. On the basis of its pharmacokinetic advantages, it is likely that the peptide analog in question or analogs based on this new design will be therapeutically advantageous for the treatment of endocrine disorders or prostate cancer. Such pharmacokinetic advantages can be particularly valuable with respect to local/direct extrapituitary effects that will be essential for more effective treatment of cancer.

\section{Materials and Methods}

Chemicals/Biological Reagents. [Des-Gly $\left.{ }^{10}, \mathrm{D}-\mathrm{Leu}^{6}, \mathrm{Pro}-\mathrm{NHEt}^{9}\right]$ GnRH (leuprolide acetate salt), Ac-D-2-Nal-4-chloro-D-Phe- $\beta$-(3-pyridyl)-D-Ala-Ser-Tyr-D-Cit-Leu-Arg-Pro-D-Ala- $\mathrm{NH}_{2}$ (cetrorelix acetate salt), and $\left[\mathrm{Des}^{-\mathrm{Gly}^{10}}{ }^{\mathrm{D}} \mathrm{D}-\mathrm{Ala}^{6}, \mathrm{Pro}-\mathrm{NHEt}^{9}\right] \mathrm{GnRH}$ [internal standard (IS), acetate salt] were purchased from Bachem AG (Bubendorf, Switzerland). [Des-Gly ${ }^{10}, \mathrm{Tyr}^{5}(\mathrm{OMe}), \mathrm{D}-\mathrm{Leu}^{6}{ }^{6}, \mathrm{Aze}^{\mathrm{N} H E t^{9}}$ ]GnRH (ana$\log 1$, acetate salt) was synthesized by the Department of Chemistry, University of Patras, Patras, Greece (Laimou et al., 2010). All solvents were LC-MS grade. Acetonitrile (Riedel-de Haën, Buchs SG, Switzerland), water (Sigma-Aldrich GmbH, Munich, Germany), ammonium acetate (Fluka, Buchs, Switzerland), formic acid (Fluka), human serum albumin (HSA) (Sigma-Aldrich $\mathrm{GmbH}$ ), dexamethasone (Riedel-de Haën), testosterone (Riedel-de Haën), Trizma base (Sigma-Aldrich $\mathrm{GmbH}$ ), sodium chloride (Fluka), sodium phosphate dibasic (Riedel-de Haën), and $\beta-\mathrm{NaDPH}$ were purchased from Sigma-Aldrich GmbH. Dithiothreitol was purchased from AppliChem GmbH (Darmstadt, Germany). Mouse plasma (CD-1) was purchased from Charles River Laboratories Italia s.r.l. (Calco, Italy). Tissues (kidneys and testes) were obtained from male C57BL/6N mice. Chinese hamster ovary-K1 cells were purchased from NEN (Waltham, MA). ${ }^{125} \mathrm{I}$-(D-Trp $\left.{ }^{6}\right)-\mathrm{GnRH}$ was purchased from PerkinElmer Life and Analytical Sciences. The androgen-dependent LNCaP-FGC (lymph node carcinoma of the prostate-fast growing colony) cell line was obtained from American Type Culture Collection (Manassas, VA). RPMI 1640 medium was purchased from Seromed, Biochrom KG (Berlin, Germany), and fetal bovine serum was obtained from Invitrogen (Paisley, Scotland).

Cell Cultures. Cells (passages 35-40) were routinely grown in RPMI 1640 medium supplemented with 10\% fetal bovine serum, glutamine (1 mM), and antibiotics (100 IU of penicillin G sodium and $100 \mu \mathrm{g} / \mathrm{ml}$ streptomycin sulfate) in a humidified atmosphere of $5 \%$ $\mathrm{CO}_{2}-95 \%$ air. In these culture conditions, the duplication period of LNCaP cells was $48 \mathrm{~h}$.

Animals. All procedures were approved by the bioethics committee of the institution and the local competent authority on the basis of the European Directive 86/609 on the protection of animals used for experimental and other scientific purposes. Male mice of the C57BL/6N inbred strain (Charles River Laboratories Italia s.r.l.) at the age of 12 weeks were randomly assigned to groups of five or six animals. Animal handling occurred before experiments, during which labeling and weighing took place. Mice were fasted overnight $(12 \mathrm{~h})$ before dosing for pharmacokinetic studies. Dosing solutions of leuprolide and analogs in saline were administered intraperitoneally. Blood sampling was performed by cardiac puncture under isoflurane anesthesia. Blood samples $(500 \mu \mathrm{l})$ were collected into low retention (Axygen, Inc., Union City, CA) microtubes containing $10 \mu \mathrm{l}$ of heparin $(5000 \mathrm{IU} / \mathrm{ml})$ and subsequently centrifuged (10 min at $3000 \mathrm{rpm}$ ) for plasma preparation. Plasma was stored in a $-80^{\circ} \mathrm{C}$ freezer until sample extraction and analysis. Tissues (kidneys and testes) were removed after the animals were sacrificed using anesthesia by isoflurane and cervical dislocation and were washed with phosphate-buffered saline, weighed, and placed in a $-80^{\circ} \mathrm{C}$ freezer until analysis.

In Vitro Stability: Mouse Kidney Membranes. Mouse kidney membrane preparations were obtained on the basis of the procedure described by Sofianos et al. (2008). Kidneys were washed with PBS, weighed, and homogenized ( $0.1 \mathrm{~g}$ wet weight $/ \mathrm{ml})$ in buffer $\mathrm{A}(100 \mathrm{mM}$ 
$\mathrm{NaCl}, 20 \mathrm{mM}$ phosphate, $\mathrm{pH}$ 7.4, $0.1 \mathrm{mg} \mathrm{HSA} / \mathrm{ml}$, and $1 \mathrm{mM}$ dithiothreitol) by a Teflon-glass homogenizer. After centrifugation at $1500 \mathrm{~g}$ for $5 \mathrm{~min}$, the supernatant was centrifuged for $60 \mathrm{~min}$ at $100,000 \mathrm{~g}$ (Sorvall Discovery 100SE ultracentrifuge; Hitachi, Yokohama, Japan). The supernatant was discarded, and the pellet was washed by addition of buffer $\mathrm{B}(100 \mathrm{mM} \mathrm{NaCl}, 20 \mathrm{mM}$ phosphate, $\mathrm{pH}$ 7.4 , and $0.1 \mathrm{mg} \mathrm{HSA} / \mathrm{ml}$ ) followed by centrifugation at $100,000 \mathrm{~g}$ for $60 \mathrm{~min}$. After the supernatant was discarded, the pellet was washed by addition of buffer $\mathrm{C}(100 \mathrm{mM} \mathrm{NaCl}$ and $20 \mathrm{mM}$ phosphate, $\mathrm{pH}$ 7.4) and the protein content was determined by the Bradford assay (Bradford, 1976). Incubation mixtures consisted of $500 \mathrm{ng} / \mathrm{ml}$ peptide (leuprolide and/ or analog 1) and $4 \mathrm{mg} / \mathrm{ml}$ protein in a final volume of $250 \mu \mathrm{l}$ of mouse kidney homogenate. Additional control samples (no kidney membranes) were prepared for each of the time points tested. The reaction was stopped by acetonitrile addition, and samples were stored at $-80^{\circ} \mathrm{C}$.

Sample extraction (samples left at room temperature to thaw for $20 \mathrm{~min}$ ) was performed by the addition of $250 \mu \mathrm{l}$ of acetonitrile-water (50:50) with $0.1 \%$ formic acid, followed by brief vortexing and sonication. Proteins were precipitated by stepwise addition of 250 and $500 \mu \mathrm{l}$ of ice-cold acetonitrile followed by brief vortexing. Samples were subsequently centrifuged $(12,000 \mathrm{~g})$ for $10 \mathrm{~min}$, and the supernatant was evaporated in a SpeedVac (SPD1010; Thermo Fisher Scientific, Waltham, MA) for $90 \mathrm{~min}$ at $50^{\circ} \mathrm{C}$. An aliquot of $100 \mu \mathrm{l}$ of mobile phase (see below) was added to each sample, and the sample was vortexed and transferred to a 96-well plate for analysis. An 1100 series system (Agilent Technologies, Waldbrown, Germany) equipped with a binary pump, autosampler, vacuum degasser, and temperature-controlled column compartment was used for analyte separation by high-performance liquid chromatography. The mobile phase consisted of solvents A (10\% acetonitrile, $90 \%$ water, $2 \mathrm{mM}$ ammonium acetate, and $0.1 \%$ formic acid) and B (90\% acetonitrile, $10 \%$ water, $2 \mathrm{mM}$ ammonium acetate, and $0.1 \%$ formic acid). An Atlantis dC18 $\mu \mathrm{m}, 2.1 \times 50 \mathrm{~mm}$ column (Waters, Milford MA) was used at a flow rate of $0.3 \mathrm{ml} / \mathrm{min}$. A linear gradient (run time of 15 $\min$ ) from $95 \% \mathrm{~A}-5 \% \mathrm{~B}$ to $50 \% \mathrm{~A}-50 \% \mathrm{~B}$ over 5 min and $50 \% \mathrm{~A}-50 \%$ $\mathrm{B}$ up to $9 \mathrm{~min}$ was used for the chromatographic separation of peptides of interest. Mass spectrometry was performed on an API 4000 Q-TRAP LC-MS/MS system fitted with a TurboIonSpray source and a hybrid triple quadrupole hybrid linear ion trap mass spectrometer (Applied Biosystems, Concord, ON, Canada). The instrument was operated in positive ion mode under the following conditions: IonSpray voltage, $5500 \mathrm{~V}$; source temperature, $550^{\circ} \mathrm{C}$; curtain gas (nitrogen) at 20; collision gas (nitrogen) at 5 ; ion source gas 1 (air) at 40; and ion source gas 2 (air) at 45 (all arbitrary units). Analog 1 (mol. wt. $1209.4 \mathrm{~g} / \mathrm{mol}$ ) was monitored by using the multiple-reaction monitoring $(\mathrm{MRM})$ transitions of $\mathrm{m} / \mathrm{z} 605.7 \rightarrow 249.2$ and $605.7 \rightarrow$ 285.4. The MRM transitions of $\mathrm{m} / z 605.5 \rightarrow 249.1$ and $605.7 \rightarrow 221.1$ were used for the detection of leuprolide (mol. wt. $1209.4 \mathrm{~g} / \mathrm{mol}$ ).

In vitro peptide stability was determined as a function of time; using the corresponding MRM transitions for each analyte, the peak areas for analog 1 and/or leuprolide (peptide concentration of 500 $\mathrm{ng} / \mathrm{ml}$ ) at $t=0$ were set as $100 \%$. Those peak areas were compared with the peak areas derived from samples at $t=0.5,1$, and $2 \mathrm{~h}$. The mean intra-assay coefficient of variation based on control samples (500 $\mathrm{ng} / \mathrm{ml}$ peptide) was less than $10 \%$. The interassay coefficients of variation for the determination of leuprolide and analog 1 were 6.6 and $6.9 \%$, respectively. Peptide monitoring by LC-MS/MS ensured specificity because both peptides had characteristic retention times $(6.79 \pm 0.01 \mathrm{~min}$ for leuprolide and $7.19 \pm 0.01 \mathrm{~min}$ for analog 1$)$ and corresponding MRM transitions. In addition, analyses of blank samples confirmed the absence of interference and established the selectivity of the assay.

Metabolism Studies: Mouse Kidney Membranes. After incubation of analog 1 with mouse kidney membrane preparations, metabolites were identified by a modification of the LC-MS/MS-based approach described above using the instrument's information-dependent acquisition feature and combining Q3 scanning followed by enhanced product ion (EPI). Information-dependent acquisition criteria were set so that a number of the most intense peaks (up to 8) would be selected for EPI analysis with a collision energy of $45 \pm 5$ $\mathrm{V}$ (leuprolide) and/or $45 \pm 10 \mathrm{~V}$ (analog 1). The semiquantitative analysis for the major metabolites identified herein was achieved by using the MRM-positive mode, as described above. Two major metabolic products were identified: a tripeptide (M-III) and a pentapeptide (M-V). M-III (mol. wt. $452.4 \mathrm{~g} / \mathrm{mol}$ ) was monitored based on the MRM transitions of $m / z 453.4 \rightarrow 176.1$ and $453.4 \rightarrow 110.2$. The MRM transitions of $m / z 688.8 \rightarrow 150.2$ and $688.8 \rightarrow 263.2$ were used for the detection of M-V (mol. wt. $687.8 \mathrm{~g} / \mathrm{mol}$ ).

In Vivo Stability and Pharmacokinetic Studies. Analog 1 was administered to male $\mathrm{C} 57 \mathrm{BL} / 6 \mathrm{~N}$ mice at $1 \mathrm{mg} / \mathrm{kg}$ i.p., and blood samples were obtained at $t=1,2,4$, and $6 \mathrm{~h}$ postdose $(n=5)$. In a parallel test group $(n=5)$, leuprolide was administered at $1 \mathrm{mg} / \mathrm{kg}$. For the quantification of peptides in plasma, stock solutions of leuprolide or analog 1 were prepared in acetonitrile-water (50:50) with $0.1 \%$ formic acid in the range of 0.5 to $5000 \mathrm{ng} / \mathrm{ml}$. A linear peptide analog of both peptides was used as the IS at the concentration of 600 $\mathrm{ng} / \mathrm{ml}$. A set of solutions at two different concentrations (50 and 500 $\mathrm{ng} / \mathrm{ml}$ ) was prepared, serving as the quality control (QC) samples. Calibration curves $(0.5-500 \mathrm{ng} / \mathrm{ml}$ for leuprolide and $5-2500 \mathrm{ng} / \mathrm{ml}$ for analog 1) and QC samples (50 and $500 \mathrm{ng} / \mathrm{ml}$ ) were prepared in plasma by addition of $20 \mu \mathrm{l}$ of leuprolide or analog 1 solutions and 25 $\mu \mathrm{l}$ of the IS solution to $50 \mu \mathrm{l}$ of mouse plasma. Samples were prepared for LC-MS/MS analysis by protein precipitation as described above. Peptide quantification was performed in the MRM-positive mode. For leuprolide and IS detection, mass spectrometry-based quantification methods were developed and validated previously (Sofianos et al., 2008). Analog 1 was monitored in mouse plasma using the MRM transitions of $\mathrm{m} / \mathrm{z} 605.7 \rightarrow 249.2$ and $605.7 \rightarrow 221.4$. A nine-point calibration curve was constructed using a $1 / x$ weighted linear regression model $(r=0.999)$. On the basis of concentrations at 50 and $500 \mathrm{ng} / \mathrm{ml}$, the intra-assay coefficient of variation for the assay was less than $6 \%$ for leuprolide detection and less than $5 \%$ for the analysis of analog 1 . The interassay coefficients of variation for analog 1 and leuprolide were 6 and 7\%, respectively.

Assay specificity and selectivity was ensured by using an LCMS/MS methodology (retention time and MRM transitions characteristic of the analyte) and analyzing blank samples to test for interferences. Based on QC samples at 50 and $500 \mathrm{ng} / \mathrm{ml}$, the accuracy of the assays for the determination of analog 1 and leuprolide in mouse plasma was 100 and $97 \%$, respectively. The lower limit of quantification for both peptides in mouse plasma was $0.5 \mathrm{ng} / \mathrm{ml}$, defined as the concentration that yielded a peak with a signal/noise ratio of 10 and at least 3 times the response compared with signal from blank extracts (samples not spiked with peptide). The accuracy and precision of the measurement at the concentration of $0.5 \mathrm{ng} / \mathrm{ml}$ were within $\pm 20 \%$.

Binding to the Human GnRH Receptor. A screening protocol was followed for the ranking of GnRH analogs (including analog 1) in terms of their binding affinities to the human $\mathrm{GnRH}$ receptor. In brief, competition binding studies were performed according to the method of PerkinElmer Life and Analytical Sciences. Frozen membrane homogenates from Chinese hamster ovary-K1 cells stably expressing the human GnRH receptor, purchased from PerkinElmer Life and Analytical Sciences, were thawed and diluted in assay buffer (25 mM Hepes, $\mathrm{pH} 7.4,10 \mathrm{mM} \mathrm{MgCl}_{2}, 1 \mathrm{mM} \mathrm{CaCl}_{2}$, and $0.5 \%$ bovine serum albumin) at a protein concentration of $0.07 \mathrm{mg} / \mathrm{ml}$. Aliquots of diluted membrane suspension $(150 \mu \mathrm{l})$ were incubated with increasing concentrations of $\mathrm{GnRH}$ analogs in the presence of $0.2 \mathrm{nM}{ }^{125} \mathrm{I}$-(D-Trp $\left.{ }^{6}\right)-\mathrm{GnRH}$ (PerkinElmer Life and Analytical Sciences) in a final volume of $0.2 \mathrm{ml}$. The mixtures were incubated at $27^{\circ} \mathrm{C}$ for $1 \mathrm{~h}$ and then filtered using a Brandel cell harvester through Whatman GF/C glass fiber filters, presoaked for $1 \mathrm{~h}$ in $0.5 \%$ polyethylenimine at $4^{\circ} \mathrm{C}$. The filters were washed nine times with $0.5 \mathrm{ml}$

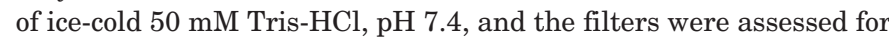
radioactivity in a gamma counter (LKB Wallac 1275 minigamma, 
$80 \%$ efficiency). Specific ${ }^{125} \mathrm{I}$-(D-Trp $\left.{ }^{6}\right)$-GnRH binding was defined as total binding less nonspecific binding in the presence of $1000 \mathrm{nM}$ $\left(D-\operatorname{Trp}^{6}\right)-G n R H$. Data for competition binding were analyzed by nonlinear regression analysis, using GraphPad Prism 4.0 (GraphPad Software, Inc., San Diego, CA), and $\log \mathrm{IC}_{50}$ values were obtained by fitting the data from competition studies to a one-site competition model. The $K_{\mathrm{i}}$ values were determined from competition data and the equation, $K_{\mathrm{i}}=\mathrm{IC}_{50} /\left(1+L / K_{\mathrm{D}}\right)$ (Cheng and Prusoff, 1973), where $L$ is the concentration of radioligand and $K_{\mathrm{D}}$ is the affinity of radioligand binding, determined from saturation studies performed by PerkinElmer Life and Analytical Sciences and under the same experimental conditions used in the present study.

To further confirm the binding to the GnRH receptor, analog 1 was evaluated in a radioligand binding assay by Ricerca Biosciences, LLC (Concord, $\mathrm{OH}$ ) as described in the literature (Halmos et al., 1996), using human recombinant Chem-1 cells, $0.05 \mathrm{nM}{ }^{125} \mathrm{I}-(\mathrm{D}-$ $\left.\operatorname{Trp}^{6}\right)-\mathrm{GnRH}$ (ligand), and $1 \mu \mathrm{M}$ (D-Trp $\left.{ }^{6}\right)-\mathrm{GnRH}$ (nonspecific ligand). Reference standards were run as an integral part of each assay to ensure the validity of the results obtained. $\mathrm{IC}_{50}$ values were determined by a nonlinear, least-squares regression analysis using $\mathrm{Ma}$ thIQ (ID Business Solutions Ltd., Guildford, Surrey, UK). The $K_{\mathrm{i}}$ values were calculated (Cheng and Prusoff, 1973) using the observed $\mathrm{IC}_{50}$ of the tested compound, the concentration of radioligand used in the assay, and the historical values for the $K_{\mathrm{D}}$ of the ligand (obtained experimentally at Ricerca Biosciences, LLC).

Efficacy Studies (Testosterone Quantification in Mouse Plasma). The ability of analog 1 to elicit testosterone release $(\mathrm{GnRH}$ receptor agonism) in mice was investigated and compared with that of leuprolide. Analog 1 was administered to male C57BL/6N mice at $1 \mathrm{mg} / \mathrm{kg}$, and blood sampling was conducted by cardiac puncture under isoflurane anesthesia at $t=1,2,4$, and $6 \mathrm{~h}$ postdose $(n=5)$. The same approach was followed in the case of vehicle (saline)- and leuprolide $(1 \mathrm{mg} / \mathrm{kg})$-treated animals $(n=5)$. Peptides and testosterone were measured in mouse plasma by an LC-MS/MS-based assay. Stock solutions of testosterone $(0.125-250 \mathrm{ng} / \mathrm{ml})$ and dexamethasone (served as the IS for testosterone quantification) were prepared in acetonitrile-water (50:50) with $0.1 \%$ formic acid. Calibration curves $(0.2-100 \mathrm{ng} / \mathrm{ml})$ and QC samples $(1,5,10$, and $40 \mathrm{ng} / \mathrm{ml})$ were prepared by adding $20 \mu \mathrm{l}$ of testosterone solutions and $25 \mu \mathrm{l}$ of dexamethasone solution $(200 \mathrm{ng} / \mathrm{ml})$ to $50 \mu \mathrm{l}$ of female CD-1 mouse plasma. Female CD-1 plasma was devoid of testosterone and, hence, was used for the construction of the standard curves and QC samples. A similar extraction protocol (protein precipitation) and chromatographic conditions as described above were used to achieve the separation of testosterone, dexamethasone, and peptides. Quantification was performed in the MRM-positive mode. For the detection of testosterone (mol. wt. $288.4 \mathrm{~g} / \mathrm{mol}$ ), the MRM transitions of $\mathrm{m} / z 289.4$ $\rightarrow 109.1$ and $289.4 \rightarrow 97.2$ were optimized, and dexamethasone (mol. wt. $392.5 \mathrm{~g} / \mathrm{mol}$ ) was monitored using the MRM transition of $\mathrm{m} / \mathrm{z}$ $393.5 \rightarrow 237.2$. A nine-point calibration curve was constructed using a $1 / x$ weighted linear regression model $(r=0.993)$.

On the basis of QC samples at 1 and $10 \mathrm{ng} / \mathrm{ml}$, the intra- and interassay coefficients of variation were less than 10 and equal to $7 \%$, respectively. The accuracy of the testosterone assay was $98 \%$. The retention times (expressed in minutes) obtained were characteristic of the analytes: $8.92 \pm 0.02$ (testosterone), $7.92 \pm 0.01$ (dexamethasone), $6.69 \pm 0.01$ (analog 1), $6.22 \pm 0.02$ (leuprolide), and $6.67 \pm 0.01$ (IS). The absence of interference was further confirmed by analyzing blank samples (female CD-1 mouse plasma). The lower limit of quantification for testosterone in mouse plasma was 0.05 $\mathrm{ng} / \mathrm{ml}$, defined as the concentration that yielded a peak with a signal/ noise ratio of 10 and at least 3 times the response compared with signal from blank extracts (samples not spiked with testosterone). The accuracy and precision of the measurement at the concentration of $0.05 \mathrm{ng} / \mathrm{ml}$ were within $\pm 20 \%$. The LC-MS/MS method that was developed and applied to our study ensured the simultaneous quantification of testosterone and peptide agonists in both plasma and testis from the same limited sample.
Dose-Response Study. To investigate and establish a dose-response relationship on the administration of analog 1 in mice, analog 1 was dosed intraperitoneally to male $\mathrm{C} 57 \mathrm{BL} / 6 \mathrm{~N}$ mice. A dose-response relationship was also investigated and determined for leuprolide. The peptides were dosed at $0.1,1,10$, and $1000 \mu \mathrm{g} / \mathrm{kg}$, and blood samples were obtained by cardiac puncture under isoflurane anesthesia at $t=1 \mathrm{~h}$ postdose $(n=5)$. The same approach was followed in the case of vehicle (saline)-treated animals $(n=5)$. Peptides and testosterone were quantified in mouse plasma as described above.

GnRH Receptor Agonism. To further confirm that testosterone release results from the binding of analog 1 to the $\mathrm{GnRH}$ receptor (agonism), analog 1 was dosed intraperitoneally to male C57BL/6N mice in the presence and absence of a known $\mathrm{GnRH}$ receptor antagonist, cetrorelix. Cetrorelix was dosed (intraperitoneally) at $1 \mathrm{mg} / \mathrm{kg}$ and after $15 \mathrm{~min}$, analog 1 was dosed either at 1 or $10 \mu \mathrm{g} / \mathrm{kg}$. In a different group, animals were treated with vehicle (saline) and after $15 \mathrm{~min}$, analog 1 was administered either at 1 or $10 \mu \mathrm{g} / \mathrm{kg}$. Likewise, $\mathrm{GnRH}$ agonism was investigated upon leuprolide dosing (at $1 \mu \mathrm{g} / \mathrm{kg}$ ). Blood sampling was conducted by cardiac puncture under isoflurane anesthesia at $t=1 \mathrm{~h}$ postdose $(n=5)$. Quantification for peptide and testosterone was performed as described above. Cetrorelix (mol. wt. $1431.1 \mathrm{~g} / \mathrm{mol}$ ) was monitored by LC-MS/MS using the MRM transitions of $m / z 716.2 \rightarrow 154.3$ and $716.2 \rightarrow 569.4$.

Cell Proliferation Assays. LNCaP cells were plated (100,000 cells/dish) in 10-cm dishes in standard culture medium. Cells were allowed to attach and start growing for 3 days; the seeding media were then changed to experimental media. Cells were treated, daily, for 7 days, with either leuprolide or with analog $1\left(10^{-6}, 10^{-8}\right.$, and $10^{-10} \mathrm{M}$ ); the medium was changed every 2 days. At the end of the treatment, cells were harvested and counted by hemocytometer. The doses of the GnRH analogs have been chosen on the basis of previous articles from Dr. Limonta's laboratory (Limonta et al., 1992, 1999).

Efficacy Based on GnRH Desensitization and Testosterone Depletion. To investigate and determine the ability of analog 1 to cause testosterone ablation upon repeated administration, a longterm repeated dosing study was conducted. Analog 1 was dosed once a day intraperitoneally to male C57BL/6N mice at $500 \mu \mathrm{g} / \mathrm{kg}$ for 20 days $(n=6)$. Vehicle (saline)-treated animals served as a control group $(n=6)$. The pharmacological effect of analog 1 was compared with that of leuprolide $(n=6)$. Blood samples were obtained by cardiac puncture under isoflurane anesthesia 1) at day $0, t=2 \mathrm{~h}$ postdose, 2) at day $9, t=2 \mathrm{~h}$ postdose, and 3 ) at day 20 . To further confirm testosterone depletion, blood samples were obtained at day $20, t=2 \mathrm{~h}$ postdose. Testes were removed at days 0,9 , and 20 and weighed and subsequently histopathologically examined; testes were fixed in $10 \%$ formalin overnight at $4^{\circ} \mathrm{C}$, followed by embedding, sectioning, and staining with hematoxylin and eosin and finally were examined under a light microscope. Analog 1, leuprolide, and testosterone concentrations were determined in both mouse plasma and testis by LC-MS/MS with minor modifications; the standard curve for the analysis of testosterone in testis was constructed using male mouse testis homogenate that was treated with activated charcoal for steroid depletion as described by Green and Leak (1987).

Statistical Analysis. The results presented herein are expressed as means \pm S.D. Statistical analyses were performed by the StatGraphics Centurion 15.206S program. Statistical significance was determined by using Student's $t$ test. Data from proliferation assays were analyzed by a Bonferroni test after one-way analysis of variance.

\section{Results}

Binding Data. The $\mathrm{IC}_{50}$ and $K_{\mathrm{i}}$ for analog 1 were 16 and $14 \mathrm{nM}$, respectively. (D-Trp $\left.{ }^{6}\right)-\mathrm{GnRH}$ was used as a control for the study, giving $\mathrm{IC}_{50}$ and $K_{\mathrm{i}}$ values of approximately $0.2 \mathrm{nM}$ (the $\mathrm{IC}_{50}$ for leuprolide is approximately $0.3 \mathrm{nM}$ on the basis 

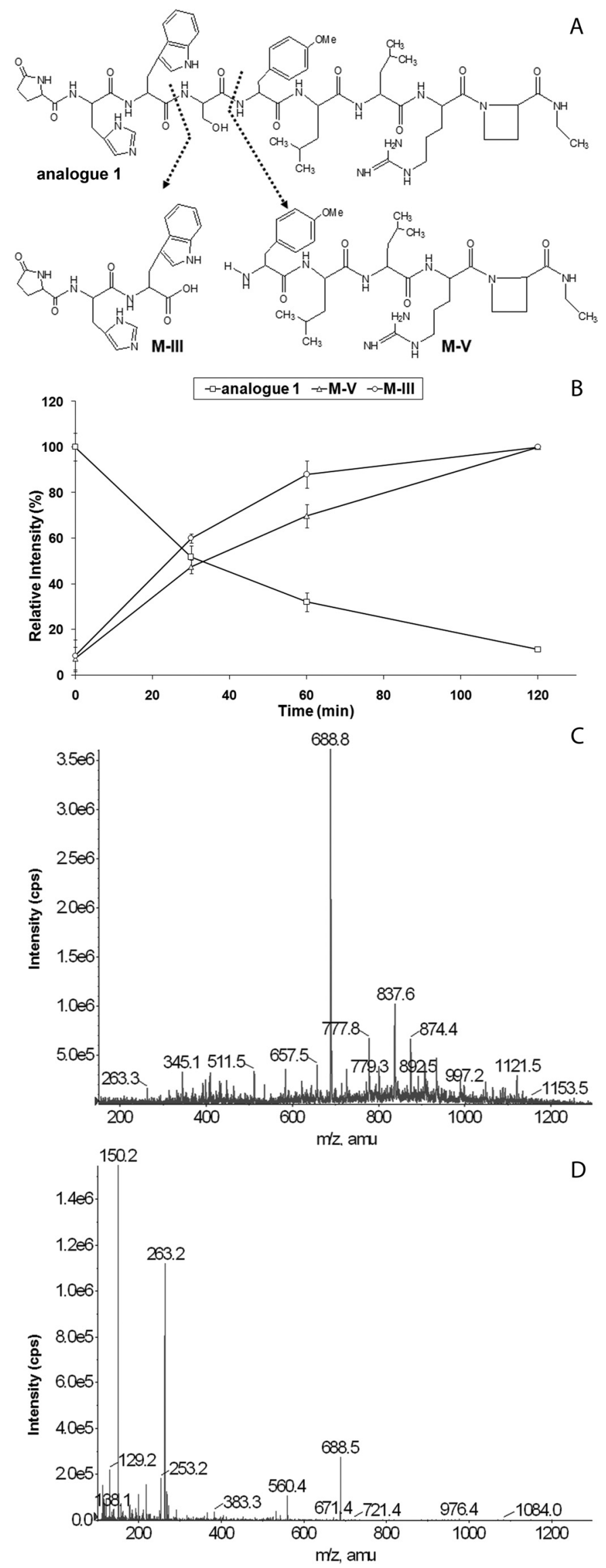

of historic data provided by Ricerca Biosciences, LLC). The results suggest that the biological activity of analog 1 is mediated through potent binding on the GnRH receptor.

In Vitro Stability and Metabolism Studies. The incubation of analog 1 with mouse kidney membrane preparations resulted in two major metabolic products: a tripeptide (M-III: pGlu ${ }^{1}-\mathrm{His}^{2}-\mathrm{Trp}^{3}-\mathrm{OH}$ ) and a pentapeptide [M-V: Tyr$(\mathrm{OMe})^{5}$-D-Leu ${ }^{6}-\mathrm{Leu}^{7}-\mathrm{Arg}^{8}-\mathrm{Aze}^{9}$-NHEt]. The proposed structures of metabolites of analog 1 are shown in Fig. 1A. Our data support the susceptibility of the $\operatorname{Trp}^{3}$-Ser $^{4}$ and $\mathrm{Ser}^{4}$ $\mathrm{Tyr}^{5}$ peptide bonds, a consistent finding based on studies that focus on GnRH and other analogs (Berger et al., 1991; Brudel et al., 1994). The approach described allowed the semiquantification of analog 1 (degradation of peptide) and M-III and M-V (formation of metabolites) as a function of time, depicted in Fig. 1B. Metabolite assignments were based on the MS and MS/MS spectra of analog 1 and its corresponding metabolites. The MS and MS/MS spectra for metabolite $\mathrm{M}-\mathrm{V}(\mathrm{m} / \mathrm{z}$ at 688.8$)$ are represented in Fig. $1, \mathrm{C}$ and D. The major product ions at $\mathrm{m} / z 150.2$ and 263.2, shown in Fig. 1D, correspond to the immonium ion of the methylated $\mathrm{Tyr}^{5}$ and the a2 fragment ion of M-V. Likewise, the major product ions for M-III at $\mathrm{m} / z 110.2$ and 221.1 correspond to the immonium ion of $\mathrm{His}^{2}$ and the a2 fragment ion of M-III (data not shown). A leuprolide metabolism/in vitro stability study was also performed, in which two major metabolites were also detected: the tripeptide described above (M-III) and a pentapeptide (M-I: Tyr ${ }^{5}$-D-Leu ${ }^{6}-\mathrm{Leu}^{7}-\mathrm{Arg}^{8}-\mathrm{Pro}^{9}$-NHEt), being consistent with those metabolites reported in the literature (Ueno and Matsuo, 1991). Analog 1 and leuprolide share a rather common peptide sequence, with differences at position 5 (analog 1 is methylated at tyrosine) and position 9 (analog 1 has an azetidine instead of proline). On the basis of the structural similarities of analog 1 and leuprolide, as was expected, M-III was a common metabolic product for the two peptides.

To determine the in vitro stability of analog 1 (and leuprolide) as a function of time, the compounds were incubated with mouse kidney membrane preparations as described. After extraction of the analytes and detection by the LCMS/MS methodology, the peak areas for both peptides were set as $100 \%$ at $t=0$. Those peak areas were subsequently compared with the peak areas derived from samples at $t=$ $0.5 \mathrm{~h}, t=1 \mathrm{~h}$, and $t=2 \mathrm{~h}$. Analog 1 was found to be significantly more stable in comparison with leuprolide; at $t=2 \mathrm{~h}$, leuprolide was extensively metabolized by mouse kidney membrane preparations, whereas $11 \%$ of analog 1 remained intact (Fig. 2A). This in vitro system also allowed compound ranking of selected GnRH analogs. The absence of metabolism of the described peptides (leuprolide, analog 1) in mouse liver microsomes (data not shown) further supports the fact that the kidney is the major site for the metabolism of leuprolide and the analog described (Carone and Peterson, 1980).

Fig. 1. A, the proposed metabolic products after the incubation of analog 1 with mouse kidney membranes. $B$, peptide degradation and metabolite (M-III and M-V) formation were monitored as a function of time. C, MS spectrum characteristic of metabolite M-V. D, EPI spectrum of M-V of ion $\mathrm{m} / \mathrm{z}$ 689. The major ions shown $(\mathrm{m} / \mathrm{z} 150.2$ and 263.2) correspond to the immonium ion of methylated $\mathrm{Tyr}^{5}$ and the a2 fragment of $\mathrm{M}-\mathrm{V}$. amu, atomic mass units. 


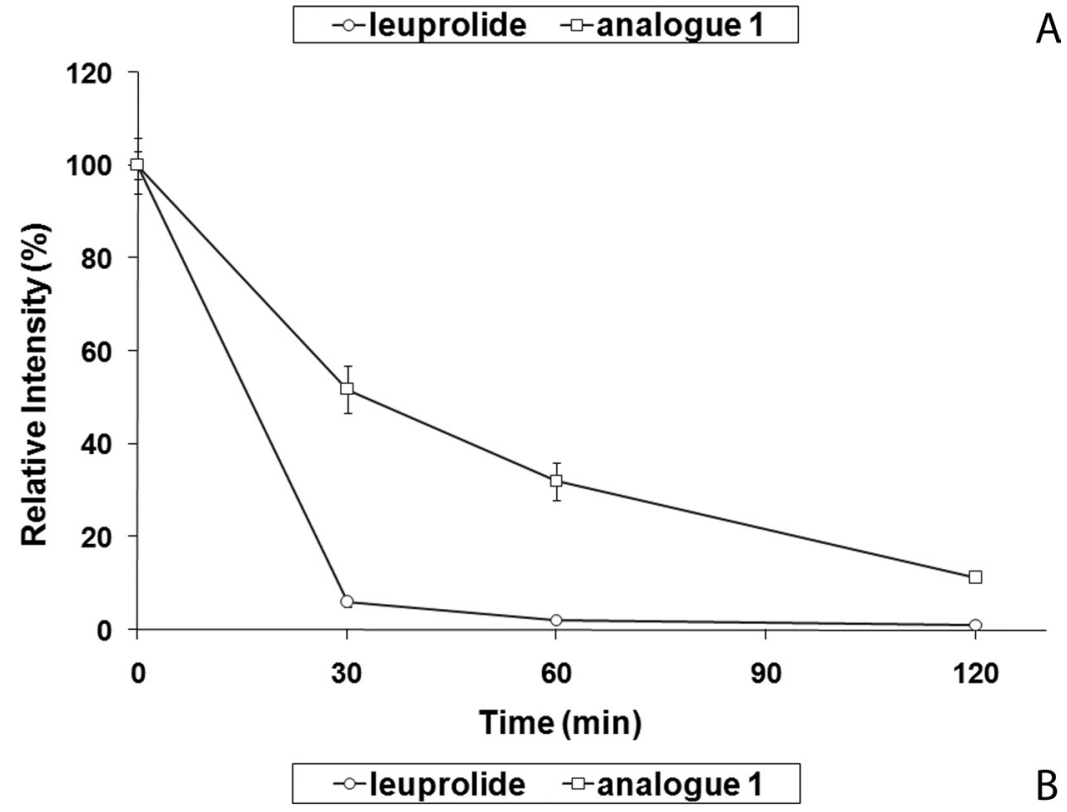

A

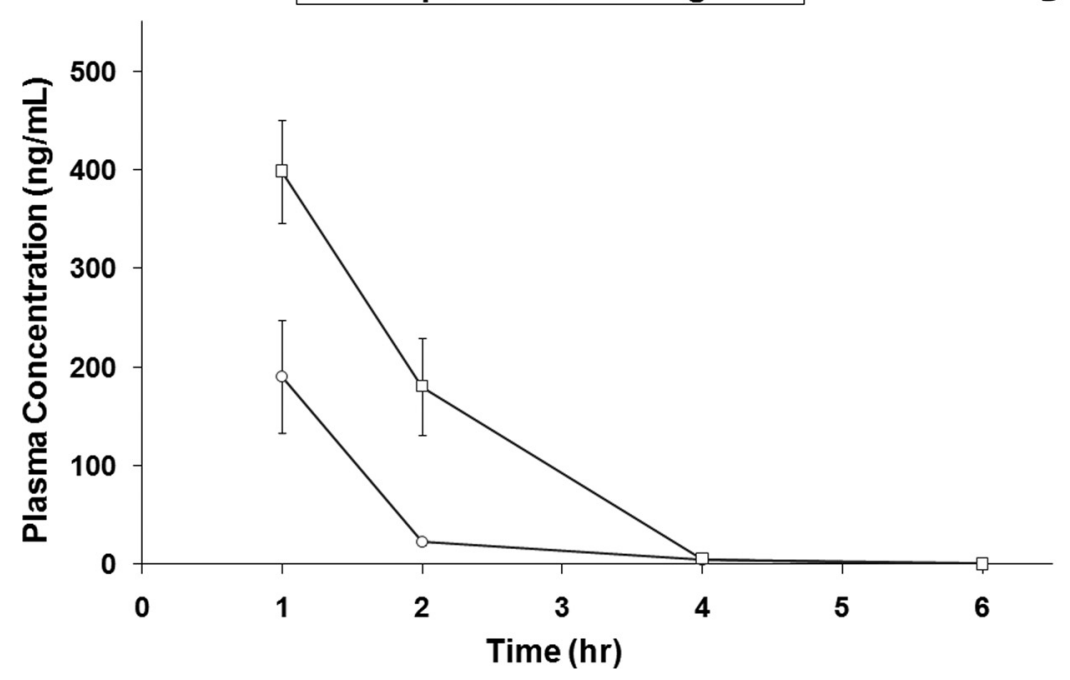

Fig. 2. A, the in vitro stability of analog 1 and leuprolide after peptide incubation with mouse kidney membrane preparations. B, the pharmacokinetic profiles (in vivo stability) of analog 1 and leuprolide after peptide administration in mice $(n=5)$ at $1 \mathrm{mg} / \mathrm{kg}$ i.p.

In Vivo Stability and Pharmacokinetic Studies. A pharmacokinetic study was conducted in mice for the evaluation of the in vivo stability of analog 1 . In parallel, the pharmacokinetic profile of leuprolide was also evaluated. A graphical representation of peptide concentrations for both analog 1 and leuprolide in mouse plasma at $t=1 \mathrm{~h}, t=2 \mathrm{~h}$, $t=4 \mathrm{~h}$, and $t=6 \mathrm{~h}$ postdose is depicted in Fig. 2B. Analog 1 exhibited a profound pharmacokinetic advantage compared with leuprolide on the basis of absolute plasma concentrations and areas under the curve (AUCs). Analog 1 dosing resulted in an $\mathrm{AUC}_{1-6 \mathrm{~h}}=479.5 \mathrm{ng} \cdot \mathrm{h} / \mathrm{ml}$, whereas the AUC value for leuprolide dosing was $\mathrm{AUC}_{1-6 \mathrm{~h}}=136.8 \mathrm{ng} \cdot \mathrm{h} / \mathrm{ml}$. Plasma peptide concentrations determined at all time points for both peptides tested showed relatively low intersubject variation. In this setting, the described in vivo pharmacokinetic protocol was also used as a comparative platform between leuprolide and other peptide analogs.

Functional Agonism of the GnRH Receptor-Testosterone Quantification in Mouse Plasma after Dosing in Mice. An efficacy study was conducted in which testosterone release was monitored upon the administration of analog 1 in mice (agonism of the $\mathrm{GnRH}$ receptor). Likewise, testosterone concentrations were determined in the plasma of leuprolidetreated mice. Testosterone plasma concentrations as a function of time ( $t=1-6 \mathrm{~h}$ postdose) are shown in Fig. 3A. Testosterone measurements in vehicle-treated mice were low as expected and in agreement with our previous studies (Sofianos et al., 2008). In comparison, testosterone concentrations in leuprolide-treated mice were significantly higher at $t=1$ to $6 \mathrm{~h}$ postdose (***, $p<0.001$ versus vehicle-treated mice). Testosterone release due to analog 1 dosing was suggestive of agonism (***, $p<0.001$ at $t=1 \mathrm{~h}, t=2 \mathrm{~h}$, and $t=$ $4 \mathrm{~h}$ versus vehicle-treated mice), showing a pattern similar to that with leuprolide treatment. In addition, Testosterone $\mathrm{AUC}_{1-6 \mathrm{~h}}$ values were equal to 244.1 and $154.9 \mathrm{ng} \cdot \mathrm{h} / \mathrm{ml}$ for leuprolide and analog 1 dosing, respectively.

To explore potential dosing regimens for efficacy studies, a dose-response relationship was established for both analog 1 and leuprolide treatment by dosing experiments in mice at $0.1,1,10$, and $1000 \mu \mathrm{g} / \mathrm{kg}$. Peptide plasma concentrations (1 $\mathrm{h}$ postdose) as a function of dose are depicted in Fig. 3B. Testosterone concentrations seemed to reach a plateau at doses higher than $10 \mu \mathrm{g} / \mathrm{kg}$ (data not shown). To demonstrate the specificity of the effects of testosterone release (i.e., bind- 

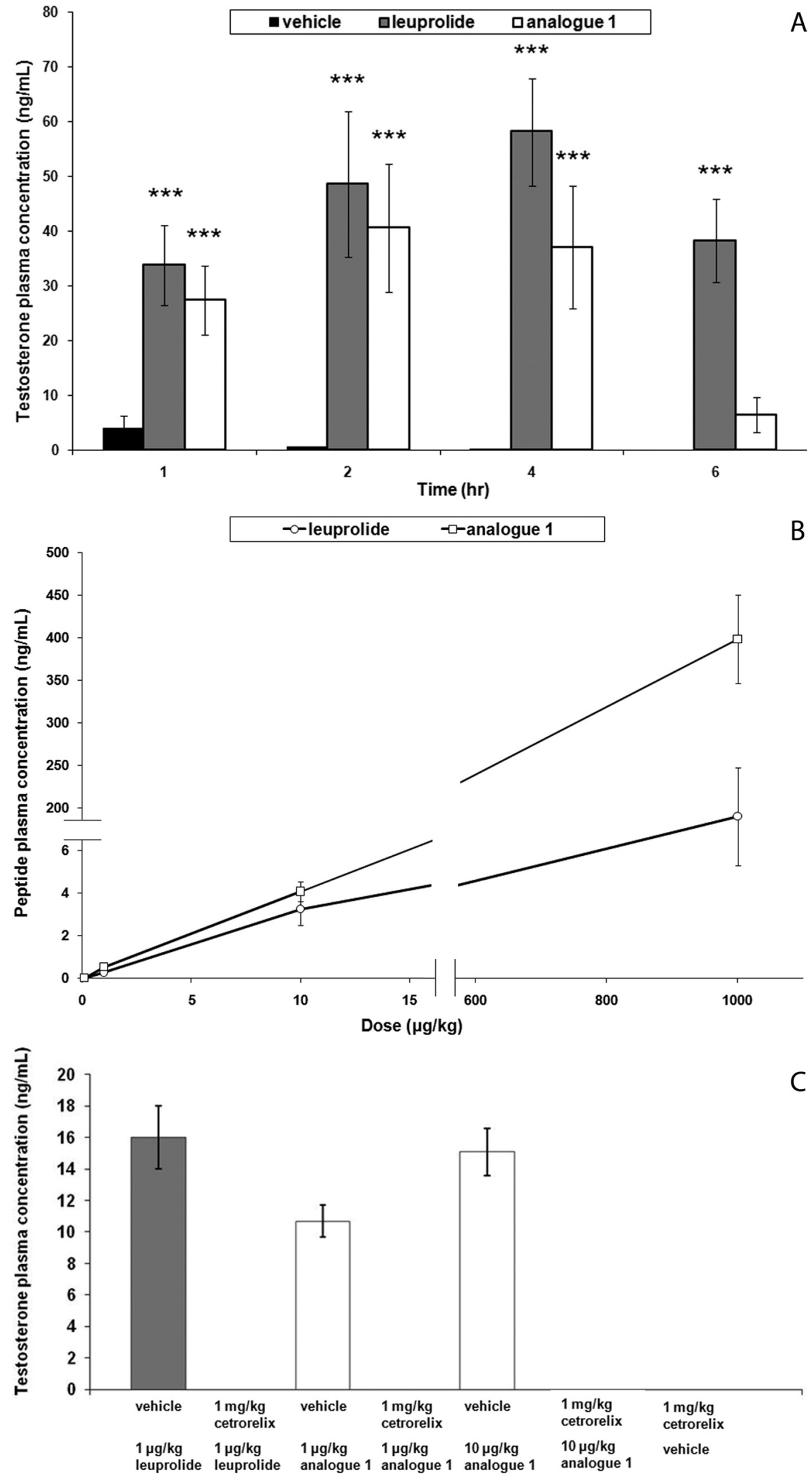

Fig. 3. A, testosterone release (functional agonism) upon analog 1 and leuprolide intraperitoneal dosing in mice $(n=5)$. The plasma testosterone concentration in vehicle-treated mice was low as expected and in agreement with previous studies. The testosterone concentration in leuprolide-treated mice was significantly higher at each time point tested (***, $p<0.001$ versus vehicle-treated mice). Testosterone release due to analog 1 dosing was suggestive of agonism $(* * *, p<0.001$ versus vehicle-treated mice at $t=$ $1 \mathrm{~h}, t=2 \mathrm{~h}$, and $t=4 \mathrm{~h}$ ), showing a pattern similar to that with leuprolide treatment. B, peptide plasma concentrations ( $1 \mathrm{~h}$ postdose) as a function of dose. In searching for appropriate doses for efficacy studies, a dose-response relationship was established for both analog 1 and leuprolide by dosing intraperitoneal experiments in mice at $0.1,1,10$, and $1000 \mu \mathrm{g} / \mathrm{kg}(n=$ 5). Testosterone concentrations seemed to reach a plateau at doses higher than $10 \mu \mathrm{g} / \mathrm{kg}$ (data not shown). C, plasma testosterone concentration upon analog 1 and leuprolide dosing in mice $(n=$ 5 ) in the presence and absence of cetrorelix to demonstrate the specificity of the effects of testosterone release. No response (no testosterone release) was observed in the presence of cetrorelix. Testosterone release is observed by the administration of peptides (either leuprolide or an$\operatorname{alog} 1)$ in the absence of cetrorelix. Values are presented as the mean \pm S.D. ing to the $\mathrm{GnRH}$ receptor and agonism by analog 1), the dosing of analog 1 was evaluated in the presence and absence of cetrorelix ( $\mathrm{GnRH}$ receptor antagonist). The administration of analog 1 in the absence of cetrorelix resulted in a robust plasma testosterone release. In contrast, no testosterone was released when analog 1 was administered after cetrorelix administration. A similar result was obtained upon leuprolide dosing in the presence and absence of cetrorelix (Fig. 3C). 


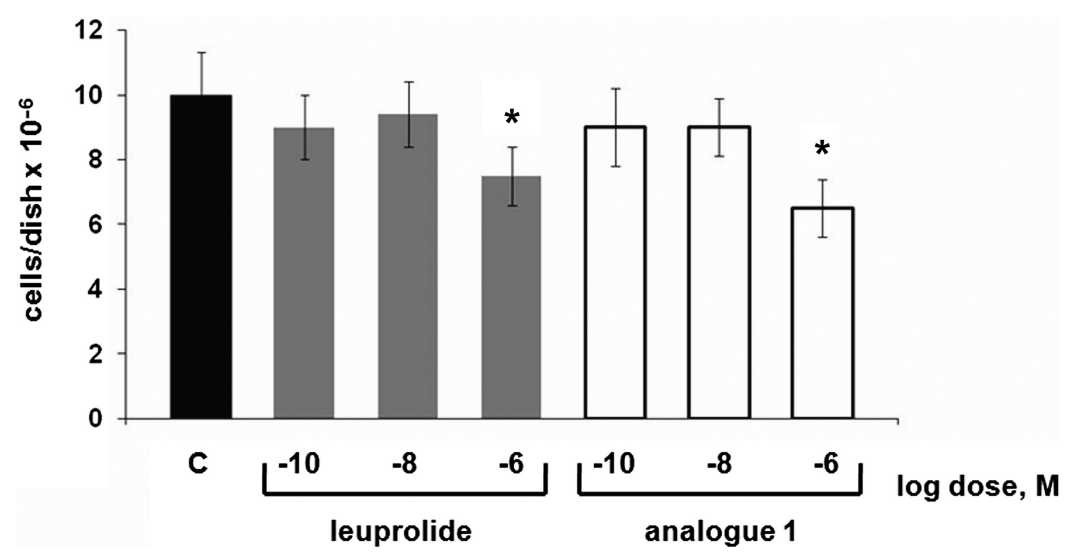

Fig. 4. Antiproliferative effect of analog 1 on LNCaP cells (hormone-dependent prostate cancer cell line). LNCaP cells were treated daily for 7 days with either leuprolide (positive control) or with analog $1\left(10^{-10}-10^{-6} \mathrm{M}\right)$. C, untreated controls. Results are expressed as the number of cells per dish and represent the results from three separate experiments. Values are presented as the mean \pm S.D. $*, p<$ 0.05 versus $\mathrm{C}$.

Antiproliferative Effect of Analog 1 on LNCaP Cells. The effect of analog $1\left(10^{-10}-10^{-6} \mathrm{M}\right)$ on the proliferation of the androgen-dependent LNCaP cells was investigated. Cells treated with the $\mathrm{GnRH}$ receptor agonist leuprolide served as the positive control. Analog 1 significantly inhibited the proliferation of $\mathrm{LNCaP}$ cells at $1 \mu \mathrm{M}(*, p<0.05$ versus controls), showing a pharmacological activity similar to that of leuprolide (Fig. 4).

Efficacy Based on GnRH Desensitization and Testosterone Depletion. The effect of repeated dosing of analog 1 $(500 \mu \mathrm{g} / \mathrm{kg}$ per day) was investigated in mice for 20 days and compared with effects caused by leuprolide. Testosterone concentrations in mouse plasma are summarized in Table 1. At day 0, peptide dosing resulted in significant testosterone release in mouse plasma compared with that in vehicletreated mice (***, $p<0.001$ for both analog 1 - and leuprolidetreated mice). At day 9, plasma testosterone concentrations of peptide-treated mice were decreased compared with those of their counterparts at day 0 but were higher than those of vehicle-treated mice, suggesting that receptor desensitization had not been accomplished. At day 20, peptide dosing resulted in a decrease by almost $50 \%$ in plasma testosterone concentration (not statistically significant), compared with that in vehicle-treated mice. With respect to testis testosterone measurements, at day 0 , peptide dosing resulted in significant testosterone release and high testis testosterone concentrations compared with those of vehicle-treated mice (***, $p<0.001$ for both analog 1- and leuprolide-treated mice). After a 20-day repeated dosing regimen for both ana$\log 1$ and leuprolide, testis testosterone was significantly decreased $(*, p<0.05)$ in comparison with that in vehicletreated mice (Fig. 5A). The testis weight of mice treated with $500 \mu \mathrm{g} / \mathrm{kg}$ analog 1 was decreased by $51 \%$ (***, $p<0.001$ versus vehicle-treated mice), whereas no body weight losses were observed. Testis atrophy was also present in leuprolidetreated mice (Fig. 5B). Histopathological examination fur-

TABLE 1

Testosterone concentrations in plasma after a 20-day repeated dosing of analog 1 or leuprolide

Data shown represent mean values \pm S.D

\begin{tabular}{lccc}
\hline \multirow{3}{*}{ Days } & \multicolumn{3}{c}{ Plasma Testosterone } \\
\cline { 2 - 4 } & $\begin{array}{c}\text { Vehicle- } \\
\text { Treated Mice }\end{array}$ & Leuprolide-Treated Mice & $\begin{array}{c}\text { Analog 1- } \\
\text { Treated Mice }\end{array}$ \\
\hline & & $n g / m l$ & \\
0 & $0.16 \pm 0.03$ & $25.3 \pm 4$ & $20.9 \pm 7$ \\
20 & $0.46 \pm 0.37$ & $0.20 \pm 0.08$ & $0.20 \pm 0.17$ \\
\hline
\end{tabular}

ther confirmed that analog 1 and leuprolide treatment resulted in remarkable atrophy of testis in mice. As shown in Fig. 6, the seminiferous epithelium became thinner and the number of the spermatogenic cells was decreased compared with that of the vehicle-treated mice.

\section{Discussion}

Based on the highly influential findings of Huggins (1963) and Schally et al. (1984), hormonal or chemical castration via the GnRH receptor became a well established strategy for the treatment of hormone-dependent cancers. Hormone-dependent cancers are not limited to the prostate and include those in other reproductive tissues such as the breast, ovaries, and endometrium. Numerous GnRH analogs have been synthesized in the context of the hormonal therapy for prostate cancer with the aim of achieving medical castration. Overall, systematic work has resulted in the synthesis of GnRH receptor agonists and antagonists, either peptides, linear or cyclic (Keramida et al., 2006), or small organic molecules (Anderes et al., 2003). More recently, degarelix, a novel GnRH receptor antagonist, was discovered. Degarelix, shown to be as effective as leuprolide in reducing testosterone in clinical trials without any evidence of systemic allergic reactions (Persson et al., 2009), was approved by the U.S. Food and Drug Administration and the European Medicines Agency for the treatment of advanced hormone-dependent prostate cancer (2009 and 2010, respectively). In addition, in the past few years diverse cytotoxic analogs targeting the GnRH receptor (cytotoxic radicals coupled to GnRH analogs that function as carriers) have been synthesized and evaluated with the intention of targeted chemotherapy (Mezo and Manea, 2010).

Although extensive research has been performed in the field of hormonal therapy, poor pharmacokinetic properties still characterize GnRH peptide analogs. Poor stability of $\mathrm{GnRH}$ analogs necessitates their subcutaneous administration (depot formulations) and leads to several side effects such as leukocytoblastic vasculitis (Turk et al., 2007) and injection site granulomas (Shiota et al., 2007). Most likely, GnRH analogs in clinical use achieve the desired pharmacological effects by action primarily on the pituitary and to a much lesser extent by direct antiproliferative effects on tumor cells. We hypothesize that stable analogs of such superagonists would be advantageous, either by allowing a reduction in dosing frequency or by allowing the use of analogs 


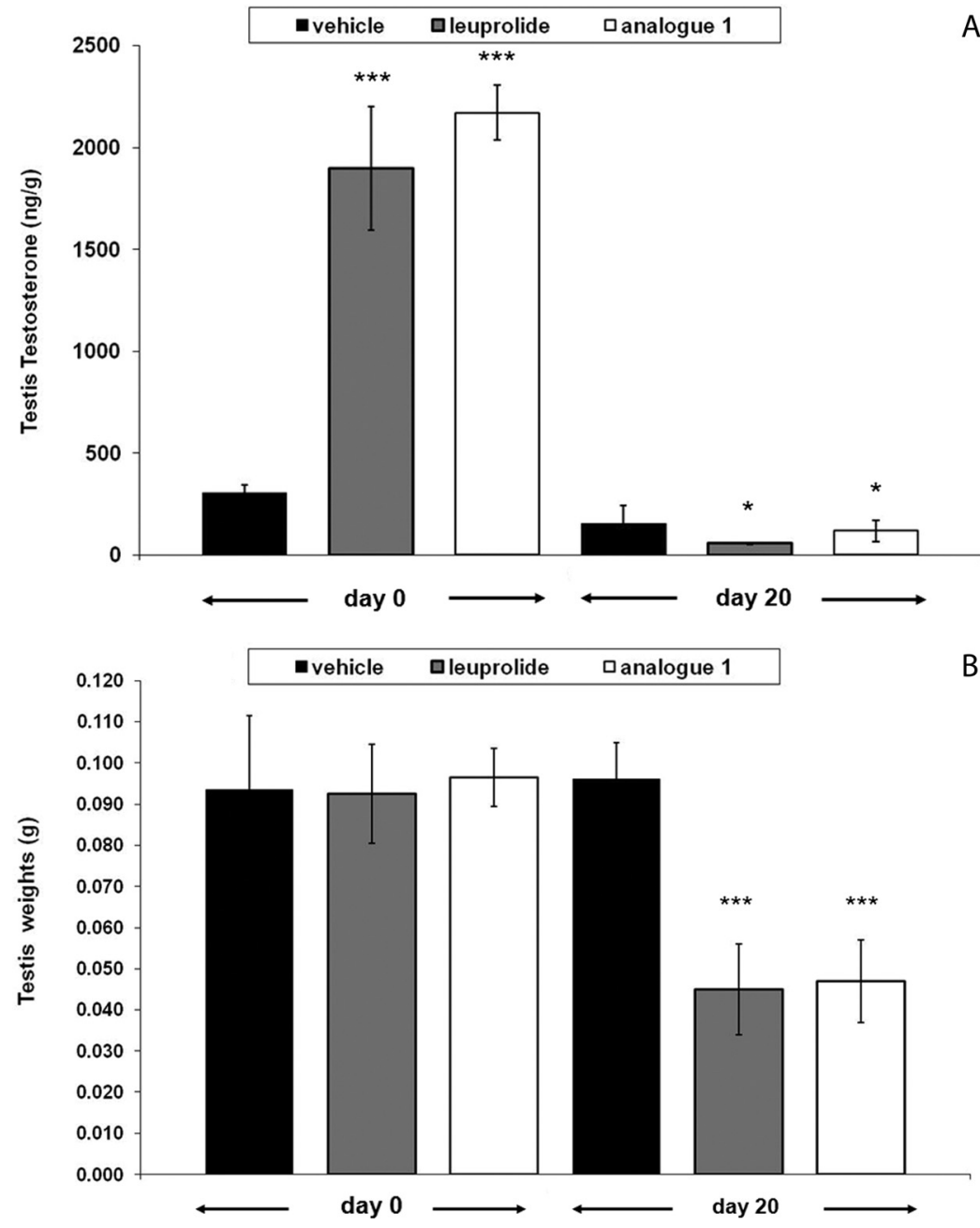

A

Fig. 5. A, testis testosterone concentrations after analog 1 or leuprolide $(500 \mu \mathrm{g} / \mathrm{kg})$ dosing in mice for 20 days $(n=6)$. At day 0 , high testis testosterone concentrations are obtained compared with those in vehicle-treated mice (***, $p<$ 0.001 for both analog 1- and leuprolide-treated mice). After a 20-day repeated dosing regimen for both analog 1 and leuprolide, testis testosterone was significantly decreased below the basal testosterone concentrations $(*, p<0.05)$ as defined by testosterone measurements in vehicle-treated mice. B, testis atrophy as a result of peptide repeated dosing. The testis weight of mice treated with $500 \mu \mathrm{g} / \mathrm{kg}$ analog 1 was decreased by $51 \%(* * *, p<0.001$ versus vehicle-treated mice), whereas no body weight losses were observed. Testis atrophy was also present in leuprolidetreated mice. Values are presented as the mean \pm S.D. that act directly on the tumor, with possible additive effects and subsequent enhancements in efficacy.

Because prostate cancer is our research area of interest, a novel GnRH receptor peptide agonist, analog 1 was synthesized with the aim of enhancing in vivo stability based on the design of leuprolide, a potent drug for the treatment of prostate cancer and other endocrine disorders (e.g., precocious puberty). In this article, we have described experimental findings regarding evaluation of analog 1, using leuprolide as a positive control. The novel peptide analog exhibited significant in vitro and in vivo metabolic stability, a critical result suggesting that modifications at positions 5 (tyrosine methylation) and 9 (azetidine instead of proline) improve metabolic stability. In comparison with analog 1 , leuprolide was metabolized at a faster rate by our in vitro system and after dosing in mice it was cleared rapidly from the plasma.

It should be noted that the enhanced metabolic stability observed with analog 1 compared with that with leuprolide is primarily due to methylation on the tyrosine residue, presumably due to steric hindrance at the site of cleavage (5-6 position) by endopeptidases. However, data from studies in our laboratory (not shown) suggest that the replacement of proline with azetidine at position 9 has an additive effect when it comes to the metabolic stability of analog 1 . Regarding the reduced binding affinity of analog 1 compared with that with leuprolide, we believe that it is consistent with analysis of ligand interactions with the GnRH receptor (Sealfon et al., 1997) according to which methylation of tyrosine on $\mathrm{GnRH}$ eliminates one of the two postulated hydrogen bonds with $\mathrm{Arg}^{8}$, thus leading to reduced binding affinity (Laimou et al., 2010). Although no single residue is crucial for $\mathrm{GnRH}$ activity, the change of proline to azetidine in position 9 is not expected to significantly affect binding affinity. We established early on in our screening efforts an excellent correlation between in vitro data (incubation of peptide with mouse kidney membranes) and in vivo stability (administration of peptide in mice and plasma monitoring as a function of time). Because it has been shown that tissue-specific metabolic degradation of the native hormone $(\mathrm{GnRH})$ by the metalloendopeptidase EP24.15 generates biologically active peptides (Cleverly and Wu, 2010), we consider understanding of the metabolism of new analogs an essential aspect of future compound optimization. It should be noted that although we have a good understanding of the metabolism of analog 1, the pharmacological significance of the metabolites presented in this article (M-III and M-V) has not been evaluated. However, based on the literature (M-III is also a metabolite of leuprolide), we hypothesize that those metabolites are not active.

A facile preclinical mouse model was developed in the context of our objectives. Intraperitoneal administration was selected, because oral administration was not practical due to the low 


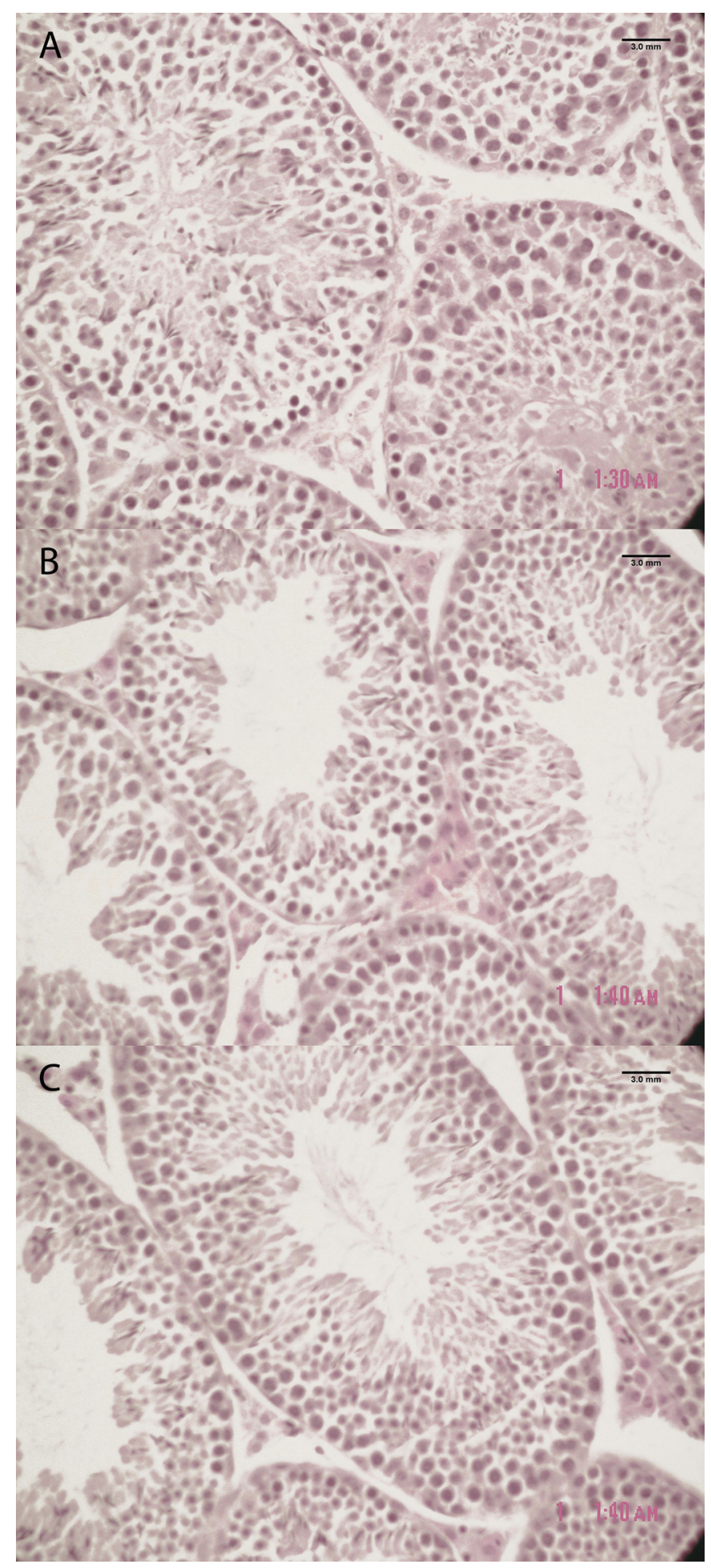

Fig. 6. A, testis from vehicle-treated mice demonstrating normal seminiferous epithelium (hematoxylin and eosin; original magnification, $400 \times)$. B, testis from mice treated with $500 \mu \mathrm{g} / \mathrm{kg}$ leuprolide. C, testis from mice treated with $500 \mu \mathrm{g} / \mathrm{kg}$ analog 1 , demonstrating a significant decrease in spermatogenic cells (hematoxylin and eosin; original magnification, $400 \times)$.

bioavailability of the peptides that were tested. The LC-MS/MSbased quantification of the selected bioactive peptides and their corresponding metabolites as well as the selective monitoring of biomarkers (e.g., testosterone) in response to drug dose, in plasma and testes, combined with the appropriate preclinical mouse model, represents a distinctive approach. The mouse model described in this article is particularly valuable, because 1 ) the human GnRH receptor is homologous to the mouse receptor (Millar et al., 2004), 2) information on in vitro and in vivo stability can be obtained with a relatively small amount of peptide (1-2 mg), 3) information on the GnRH receptor agonism (receptor specific in vivo modulation) can be obtained by using testosterone as a marker, 4) it allows the determination of the dosing regimen required for efficacy based on action on the pituitary, and 5) it can become the basis of follow-up experiments on genetically modified mouse animal models or other tumor xenografted mouse models (Sharpless and Depinho, 2006; Morgan et al., 2008).

The robust sensitive methodology that we developed for the quantification of testosterone in mouse plasma $(0.05-100$ $\mathrm{ng} / \mathrm{ml})$ or determination of testosterone in testis (2-2000 $\mathrm{ng} / \mathrm{g}$ ) gives us an excellent understanding of compound efficacy assessment. Because endogenous testosterone plasma concentrations of control animals are low $(\sim 0.2 \mathrm{ng} / \mathrm{ml})$, by using our methodology it is difficult to establish "castration" plasma values for treated animals, an anticipated effect after dosing. However, the high concentrations of testosterone in testis (average control values of $305 \mathrm{ng} / \mathrm{g}$ ) allowed us to easily distinguish between control and treated values. After the 20-day treatment, average testis concentrations in leuprolide- or analog 1-treated animals were 58 and $118 \mathrm{ng} / \mathrm{g}$, respectively. Moreover, the testis weights of the treated animals were significantly lower in comparison with those of the control group (atrophy induced by dosing), thus making the differences in testosterone testis concentration between control and peptide-treated animals even more pronounced. Although the binding affinity of analog 1 on the GnRH receptor was not as high as the binding affinity of leuprolide $(\sim 15$ versus $<1 \mathrm{nM})$, the in vivo efficacy between the two analogs was similar (at the tested dose), suggesting that the enhanced stability or bioavailability of analog 1 compensates for binding affinity differences. Proliferation studies based on a hormone-dependent prostate cancer cell line (LNCaP cells) indicated that analog 1 was as potent as the superagonist leuprolide in terms of inhibiting cell proliferation. It is possible that analog 1 can play a significant role for the treatment of hormone-dependent cancers, by acting not only at the pituitary level (thus suppressing the pituitary-testicular axis) but also by exerting antitumor activity directly on cancer cells, as has been previously shown for other $\mathrm{GnRH}$ agonists (Maudsley et al., 2004; Montagnani Marelli et al., 2006). On the basis of the binding affinities of both analogs (leuprolide or analog 1), perhaps antiproliferative effects should have been expected at nanomolar concentrations. However, our studies with the LNCaP cell line showed that significant effects were only observed at the $10^{-6} \mathrm{M}$ concentration. Although recent studies that used the superagonist D-Trp ${ }^{6}$-GnRH-I as a positive control show that with certain cell lines (e.g., transfected HEK293 cells), growth inhibition can be achieved at $5 \mathrm{nM}$ agonist concentrations (Morgan et al., 2008); the same studies demonstrate elegantly that cell receptor levels and cell context are critical for cell responses. Thus, the potential of analog 1 for the treatment of prostate cancer will have to be further investigated by taking into consideration $\mathrm{GnRH}$ receptor levels and cell context and testing in animal models that address antiproliferative effects.

In conclusion, our belief is that the discovery of $\mathrm{GnRH}$ 
analogs, such as analog 1 or analogs based on this new design with features that lead to enhanced in vivo stability and in vivo potency similar to that of leuprolide could result in valuable alternatives for the treatment of prostate cancer.

\section{Acknowledgments}

We thank Anna Agapaki from the Histochemistry Unit for assistance with tissue processing.

\section{Authorship Contributions}

Participated in research design: Balafas, Tselios, Kostomitsopoulos, Matsoukas, and Tamvakopoulos.

Conducted experiments: Katsila, Liapakis, Limonta, Marelli, Gkountelias, and Kostomitsopoulos.

Contributed new reagents or analytic tools: Katsila, Liapakis, Limonta, and Tamvakopoulos.

Performed data analysis: Katsila and Tamvakopoulos.

Wrote or contributed to the writing of the manuscript: Katsila and Tamvakopoulos.

\section{References}

Adjei A, Love S, Johnson E, Diaz G, Greer J, Haviv F, and Bush E (1993) Effect of formulation adjuvants on gastrointestinal absorption of leuprolide acetate. J Drug Target 1:251-258.

Anderes KL, Luthin DR, Castillo R, Kraynov EA, Castro M, Nared Hood K, Gregory ML, Pathak VP, Christie LC, Paderes G, et al. (2003) Biological characterization of a novel, orally active small molecule gonadotropin-releasing hormone $(\mathrm{GnRH})$ antagonist using castrated and intact rats. J Pharmacol Exp Ther 305:688-695.

Berger H, Heinrich N, Albrecht E, Kertscher U, Oehlke J, Bienert M, Schäfer H, Baeger I, and Mehlis B (1991) Gonadotropin-releasing hormone ( $\mathrm{GnRH})$ analogs: relationship between their structure, proteolytic inactivation and pharmacokinetics in rats. Regul Pept 33:299-311.

Bradford MM (1976) A rapid and sensitive method for the quantitation of microgram quantities of protein utilizing the principle of protein-dye binding. Anal Biochem 72:248-254.

Brudel M, Kertscher U, Berger H, and Mehlis B (1994) Liquid chromatographicmass spectrometric studies on the enzymatic degradation of gonadotropinreleasing hormone. J Chromatogr A 661:55-60.

Carone FA and Peterson DR (1980) Hydrolysis and transport of small peptides by the proximal tubule. Am J Physiol 238:F151-F158.

Cheng Y and Prusoff WH (1973) Relationship between the inhibition constant $\left(K_{\mathrm{i}}\right)$ and the concentration of inhibitor which causes 50 per cent inhibition $\left(\mathrm{I}_{50}\right)$ of an enzymatic reaction. Biochem Pharmacol 22:3099-3108.

Cleverly K and Wu TJ (2010) Is the metalloendopeptidase EC 3.4.24.15 (EP24.15), the enzyme that cleaves luteinizing hormone-releasing hormone (LHRH), an activating enzyme? Reproduction 139:319-330.

Culig Z, Hobisch A, Cronauer MV, Radmayr C, Trapman J, Hittmair A, Bartsch G, and Klocker $H$ (1994) Androgen receptor activation in prostatic tumor cell lines by insulin-like growth factor-I, keratinocyte growth factor, and epidermal growth factor. Cancer Res 54:5474-5478.

Green B and Leak RE (1987) Steroid Hormones: A Practical Approach, IRL Press, Oxford, UK.

Halmos G, Schally AV, Pinski J, Vadillo-Buenfil M, and Groot K (1996) Downregulation of pituitary receptors for luteinizing hormone-releasing hormone (LH$\mathrm{RH})$ in rats by LH-RH antagonist Cetrorelix. Proc Natl Acad Sci USA 93:23982402 .

Haviv F, Fitzpatrick TD, Nichols CJ, Swenson RE, Bush EN, Diaz G, Nguyen A, Nellans HN, Hoffman DJ, Ghanbari H, et al. (1992) Stabilization of the N-terminal residues of the luteinizing hormone-releasing hormone agonists and the effect on pharmacokinetics. J Med Chem 35:3890-3894.

Huggins CB (1963) The hormone-dependent cancers. Bull NY Acad Med 39:752-757.

Johns WD, Garnick MB, and Kaplan WD (1990) Leuprolide therapy for prostate cancer. An association with scintigraphic "flare" on bone scan. Clin Nucl Med 15:485-487.

Keramida MK, Tselios T, Mantzourani E, Papazisis K, Mavromoustakos T, Klaussen C, Agelis G, Deraos S, Friligou I, Habibi H, et al. (2006) Design, synthesis, and molecular modeling of a novel amide-linked cyclic GnRH analogue cyclo(49) $\left[\mathrm{Lys}^{4}, \mathrm{D}-\operatorname{Trp}^{6}{ }^{6}, \mathrm{Glu}^{9}\right] \mathrm{GnRH}$ : stimulation of gonadotropin gene expression. J Med Chem 49:105-110.

Kirby RS, Fitzpatrick JM, and Clarke N (2009) Abarelix and other gonadotrophinreleasing hormone antagonists in prostate cancer. BJU Int 104:1580-1584

Labrie F, Bélanger A, Luu-The V, Labrie C, Simard J, Cusan L, Gomez J, and
Candas B (2005) Gonadotropin-releasing hormone agonists in the treatment of prostate cancer. Endocr Rev 26:361-379.

Laimou DK, Katsara M, Matsoukas MT, Apostolopoulos V, Troganis AN, and Tselios TV (2010) Structural elucidation of Leuprolide and its analogues in solution: insight into their bioactive conformation. Amino Acids 39:1147-1160.

Limonta P, Dondi D, Moretti RM, Maggi R, and Motta M (1992) Antiproliferative effects of luteinizing hormone-releasing hormone agonists on the human prostatic cancer cell line LNCaP. J Clin Endocrinol Metab 75:207-212.

Limonta P, Moretti RM, Marelli MM, Dondi D, Parenti M, and Motta M (1999) The luteinizing hormone-releasing hormone receptor in human prostate cancer cells: messenger ribonucleic acid expression, molecular size, and signal transduction pathway. Endocrinology 140:5250-5256.

Matsoukas J, Keramida M, Panagiotopoulos D, Mavromoustakos T, Maia HLS, Bigam G, Pati D, Habibi HR, and Moore GJ (1997) Structure elucidation and conformational analysis of gonadotropin releasing hormone and its novel synthetic analogue [Tyr(OMe)5,d-Lys6,Aze9NHEt]GnRH: the importance of aromatic clustering in the receptor binding activity. Eur J Med Chem 32:927-940.

Maudsley S, Davidson L, Pawson AJ, Chan R, López de Maturana R, and Millar RP (2004) Gonadotropin-releasing hormone $(\mathrm{GnRH})$ antagonists promote proapoptotic signaling in peripheral reproductive tumor cells by activating a $G_{\text {alphai }}$-coupling state of the type I GnRH receptor. Cancer Res 64:7533-7544.

Mezo G and Manea M (2010) Receptor-mediated tumor targeting based on peptide hormones. Expert Opin Drug Deliv 7:79-96.

Millar RP, Lu ZL, Pawson AJ, Flanagan CA, Morgan K, and Maudsley SR (2004) Gonadotropin-releasing hormone receptors. Endocr Rev 25:235-275.

Montagnani Marelli M, Moretti RM, Januszkiewicz-Caulier J, Motta M, and Limonta P (2006) Gonadotropin-releasing hormone (GnRH) receptors in tumors: a new rationale for the therapeutical application of $\mathrm{GnRH}$ analogs in cancer patients? Curr Cancer Drug Targets 6:257-269.

Montagnani Marelli M, Moretti RM, Mai S, Procacci P, and Limonta P (2007) Gonadotropin-releasing hormone agonists reduce the migratory and the invasive behavior of androgen-independent prostate cancer cells by interfering with the activity of IGF-I. Int J Oncol 30:261-271.

Montagnani Marelli M, Moretti RM, Mai S, Procacci P, and Limonta P (2008) Gonadotropin-releasing hormone receptor levels and cell context affect tumor cell responses to agonist in vitro and in vivo. Cancer Res 68:6331-6340.

Pawson AJ, Faccenda E, Maudsley S, Lu ZL, Naor Z, and Millar RP (2002) A six-month, open-label study assessing a new formulation of leuprolide $7.5 \mathrm{mg}$ for suppression of testosterone in patients with prostate cancer. Clin Ther 24:19021914.

Pawson AJ, Faccenda E, Maudsley S, Lu ZL, Naor Z, and Millar RP (2008) Mammalian type I gonadotropin-releasing hormone receptors undergo slow, constitutive, agonist-independent internalization. Endocrinology 149:1415-1422.

Persson BE, Kold Olesen T, and Jensen JK (2009) Degarelix: a new approach for the treatment of prostate cancer. Neuroendocrinology 90:235-244.

Schally AV, Redding TW, and Comaru-Schally AM (1984) Potential use of analogs of luteinizing hormone-releasing hormones in the treatment of hormone-sensitive neoplasms. Cancer Treat Rep 68: 281-289.

Sealfon SC, Weinstein H, and Millar RP (1997) Molecular mechanisms of ligand interaction with the gonadotropin-releasing hormone receptor. Endocr Rev 18: 180-205.

Sennello LT, Finley RA, Chu SY, Jagst C, Max D, Rollins DE, and Tolman KG (1986) Single-dose pharmacokinetics of leuprolide in humans following intravenous and subcutaneous administration. J Pharm Sci 75:158-160.

Sharpless NE and Depinho RA (2006) The mighty mouse: genetically engineered mouse models in cancer drug development. Nat Rev Drug Discov 5: 741-754.

Shiota M, Tokuda N, Kanou T, and Yamasaki H (2007) Incidence rate of injectionsite granulomas resulting from the administration of luteinizing hormonereleasing hormone analogues for the treatment of prostatic cancer. Yonsei Med $J$ 48:421-424.

Sofianos ZD, Katsila T, Kostomitsopoulos N, Balafas V, Matsoukas J, Tselios T, and Tamvakopoulos C (2008) In vivo evaluation and in vitro metabolism of leuprolide in mice-mass spectrometry-based biomarker measurement for efficacy and toxicity. J Mass Spectrom 43:1381-1392.

Turk BG, Dereli T, Dereli D, and Akalin T (2007) Leuprolide acetate-induced leukocytoclastic vasculitis. Acta Obstet Gynecol Scand 86:892-893.

Ueno H and Matsuo S (1991) High-performance liquid chromatography followed by radioimmunoassay for the determination of a luteinizing hormone-releasing hormone analogue, leuprorelin, and its metabolite. J Chromatogr 566:57-66.

Wirth MP, Hakenberg OW, and Froehner M (2007) Optimal treatment of locally advanced prostate cancer. World $J$ Urol 25:169-176.

Zheng Y, Qiu Y, Lu MF, Hoffman D, and Reiland TL (1999) Permeability and absorption of leuprolide from various intestinal regions in rabbits and rats. Int J Pharm 185:83-92.

Address correspondence to: Dr. Tamvakopoulos Constantin, Division of Pharmacology-Pharmacotechnology, Biomedical Research Foundation, Academy of Athens, Athens, Greece. E-mail: ctamvakop@bioacademy.gr 